\author{
Cadernos de \\ ESTUDOS LINGUÍSTIICOS - (58.3), Campinas, pp. 521-533 - set./dez. 2016
}

\title{
ENGLISH IN NEW YORK, 50 YEARS AFTER
}

\author{
GREGORY R. GUY ${ }^{1}$
}

\begin{abstract}
Labov's classic account of New York City English in 1966 identified a number of distinctive phonological characteristics that were sociolinguistically stratified, by speakers' age, class, and speech style. The evidence indicated that many of the variants most associated with the city dialect were socially stigmatized, and some were involved in ongoing change. A comparison of those results with recent studies of the city provides a unique perspective on how those changes have progressed over fifty years. Broadly speaking, most of the features formerly typical of New York City English have receded or disappeared, continuing trends that were already evident in Labov's study. The social stigma accorded those features was the likely motivation for these changes.

Keywords: phonological variation, real time language change, New York City English.
\end{abstract}

RESUMO: A clássica obra de Labov de 1966 sobre o inglês da cidade de Nova Iorque identificou uma série de características fonológicas, estratificadas sociolinguisticamente de acordo com a idade, classe social e estilo dos falantes. Os resultados indicaram que muitas das variantes associadas com o dialeto da cidade eram socialmente estigmatizadas, e que algumas estavam em processo de mudança. Uma comparação desses resultados com estudos mais recentes sobre a cidade fornece uma perspectiva singular sobre como tais mudanças se desenvolveram ao longo de 50 anos. Em termos gerais, a maior parte das características outrora típicas do inglês de Nova Iorque recuaram ou desapareceram, em continuação a tendências que já eram evidentes no estudo de Labov. O estigma social atribuído a essas características foi a provável motivação para as mudanças.

Palavras-chave: variação fonológica, mudança linguística em tempo real, inglês de Nova Iorque.

\section{INTRODUCTION}

William Labov's monumental study (1966; republished second edition 2006) of New York City English became the founding document of variationist sociolinguistics, but it was also a detailed and comprehensive analysis of the largest urban speech community in the United States. Labov presented a portrait of the language of this community that revealed its ethnic differentiation, its articulation with the prevailing social class structure and the associated ideology of prestige and status, and its dynamic properties, reflected in a number of ongoing changes. Now, after more than 50 years since Labov's original fieldwork on the Lower East Side of Manhattan, we have an excellent opportunity to advance and deepen our understanding of these sociolinguistic properties and processes through a re-examination of the state of the language in the quintessential North American mega-city.

\footnotetext{
${ }^{1}$ New York University.
} 
Unsurprisingly, the dynamism evident in the 1960s continues; the changes that were evident in Labov's work have advanced, and new social and linguistic developments are apparent. The ethnic and linguistic diversity of this always heterogeneous city is now still more profound. About one-quarter of New Yorkers are African-American and about one-eighth have Asian ancestry. In the latest US Census figures, almost half of the people in the city report speaking a language other than English at home, and more than one-third of city residents are foreign born. English in New York today co-exists and commingles with a very long list of other languages, including representatives from every region of the world. Most notable is the presence of some two million Spanish speakers - a quarter of the population. This places New York among the top ten most populous Spanishspeaking cities in the world; it has more Spanish speakers than the capital cities of 11 Latin American countries. And even the English-speaking population is heterogeneous: the city attracts substantial internal migration from all over the United States, as well as international migration from English speaking countries such as Britain, Canada, and Ireland.

Such linguistic diversity and demographic dynamism suggests an important question: what is the status of the city as a speech community characterized by a distinctive local dialect of English? What are the prospects for local dialect maintenance in a city where locally born and raised native speakers of English are a minority, in constant linguistic contact with speakers of other dialects of English and other languages? Indeed, what is the value of linguistically indexing a local identity in so global a city? A comparison of Labov's findings from the 1960s with contemporary studies provides a real-time perspective on these questions.

\section{NYCE THEN}

Historically New York City English (NYCE) has been identified with a set of phonetic, phonological and lexical features. It was one of the three 'r-less' regions of the United States (along with Eastern New England and the lowlands of the South), which accompanied the 18th century sound change in Southern England in which coda (r) was vocalized or deleted. Additionally the retroflex or ' $r$-colored schwa' syllabic nucleus in bird, herd lost r-coloring and became realized as a diphthong starting in a mid-central position with a high front off-glide. NYCE also had relatively high rates of stopping or affrication of the interdental fricatives (TH) and (DH). And it had several distinctive vocalic properties, notably a raised back nucleus followed by a low central off-glide for the BOUGHT vowel, and a splitting of the TRAP vowel /æ/ into two allophones, a low front lax monophthong, and a tense diphthong phonetically analogous to the BOUGHT vowel, with a raised, fronted nucleus and a centralizing off-glide. This tense variant had a distinctive distribution. It had strong phonological conditioning, being found in most words where it was followed in a closed syllable by a voiceless fricative (e.g., half, path, pass), a voiced stop ( $c a b$, mad, bag), and front nasals (man, ham, but not hang). But there were also lexically specific exceptions to this pattern, such as tense avenue. 
In 1966, Labov found that all of these features of NYCE were realized variably in the usage of his consultants, showing distinctive patterns of social, stylistic and ethnic distribution. The vocalic variables showed some ethnic differentiation: Labov's speakers with Italian backgrounds tended to use more open variants of BOUGHT, but more raised and fronted variants of tense /æ/, while his Jewish speakers did the reverse: more BOUGHT raising, less /æ/ raising. The rhotic and fricative variables showed striking social and stylistic stratification, in which the local variants were used more by lower status speakers and in more casual styles, while the alternative variants, more characteristic of neighboring American English dialects, were favored by speakers of higher socio-economic status and by all speakers in more careful, self-monitored styles. Figures 1 and 2 illustrate this pattern.

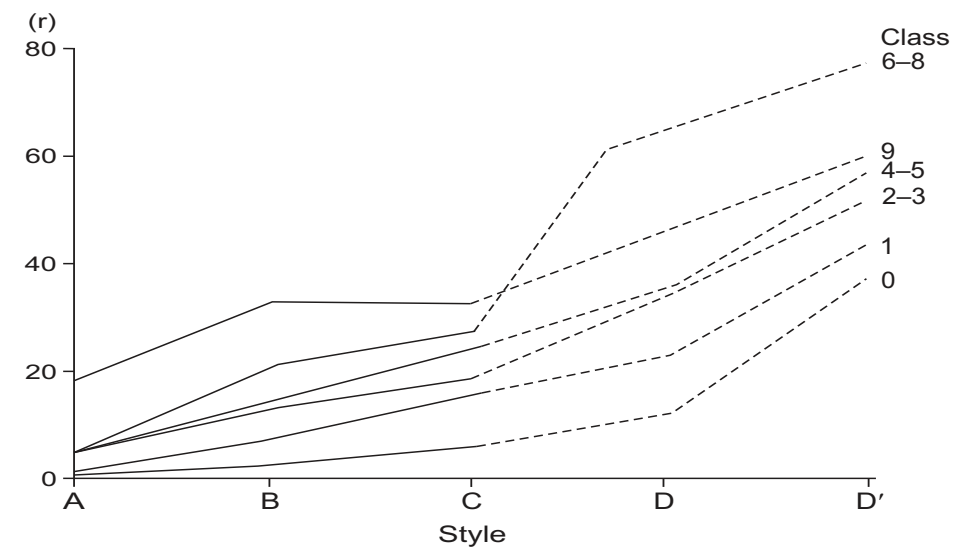

Figure 1: Class and style stratification of coda (r) (Source: Labov 2006 [1966]:152, Fig. 7.11)

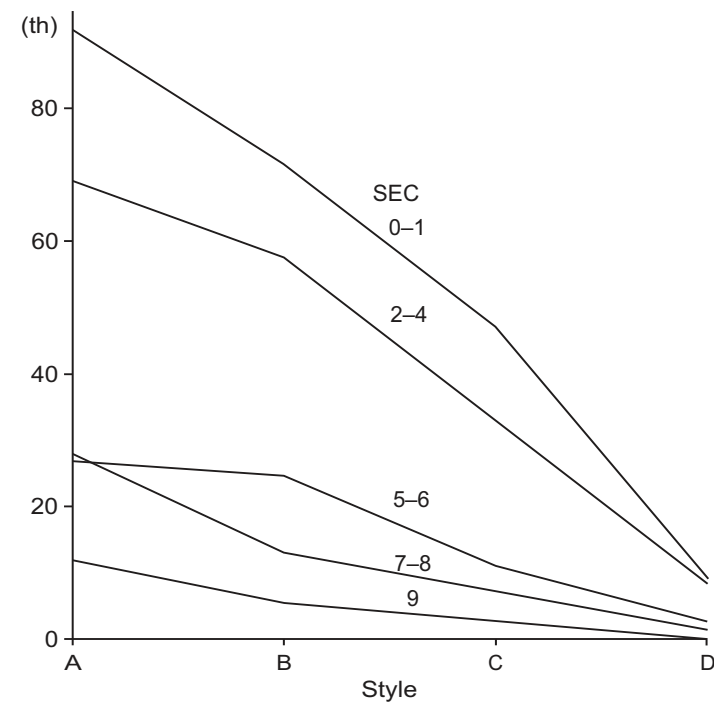

Figure 2: Class and style stratification of (TH) (Source: Labov 2006 [1966]:167, Fig. 7.23) 
In these data, speakers are grouped according to socioeconomic class (SEC), defined by a composite measure of education, occupation, and income, ranging from 0 (lowest) to 9 (highest). The style dimension is intended to reflect an informal to formal range, with A being the most casual style. In Figure 1, the (r) index is the percent of relevant words in which (r) was realized with rhotic articulation, rather than vocalized or deleted. This value increases with social status of speakers, and with more careful styles. Higher class is associated with more /r/, and everybody uses more $/ \mathrm{r}$ / when they are speaking more carefully.

The $(\mathrm{TH})$ variable shows the same pattern. Here the index is a weighted average of the numbers of tokens realized with a stop, affricate, or fricative, ranging from a low of 0 (all fricatives) to a high of 200 (all stops). As the figure indicates, the lowest status speakers use the most occlusive pronunciations, and all speakers avoid occlusive realizations in their more careful styles. This distribution reflects a normative ideology that privileges 'standard' or prestige variants - usually those preferred by elite speakers - over 'nonstandard' variants, in this case ones that are characteristic of NYCE. In other words, NYCE variants are associated with some level of stigma, at least for some speakers and some social contexts.

Of particular note in Labov's results is the evidence that these variables are involved in change in progress. This is demonstrated by the distribution of variants in apparent time, i.e. across different age groups in the population. A significant agerelated trend in the use of a variant is in most cases associated with an ongoing change in the direction of the variant preferred by younger speakers. Labov divides such changes into two types, with distinct social motivations. Spontaneous innovations emerging within the local community are characterized as 'change from below'. In a long series of studies, culminating in his three-volume work Principles of Linguistic Change (1994, 2001, 2010), Labov argues that such changes are typically led neither by the highest or lowest status speakers, but by groups in the interior of the socioeconomic hierarchy, sometimes labeled the lower-middle class. In the early stages of such a change, the innovation often displays no stylistic variation. But a different class and style distribution is found for cases of 'change from above', which involve the adoption of a prestige variant usually modeled on a source external to the local community. Such changes will most commonly be led by the highest status groups in the community, and will show stylistic variation in which the innovative form is preferred in more careful styles.

Most of the variables that Labov examined show some apparent time evidence of change in progress. Perhaps the clearest is the decline of the diphthongal variant of nuclear ( $\mathrm{r}$ ). This variant has long been the object of overt stigma, stereotyped in print as oi, as in boid and toidy-toid (for bird, thirty-third). Perhaps unsurprisingly, it was rapidly receding in apparent time. In Figure 3 we see that all the youngest generation of all but the lowest status groups have completely abandoned this variant by 1966 , whereas for speakers over 50, this was the most common variant. The highest status group has zero instances of this variant at all age levels, suggesting that they were the first to shift away from this historical characteristic of NYCE. This is consistent with a change from above, replacing the old NYCE variant with the rhotic pronunciation typical of most American English dialects. The unanimity of all social class groups as to the direction of change indicates that this change is fairly mature: it has been underway for some time and is in fact approaching completion. 


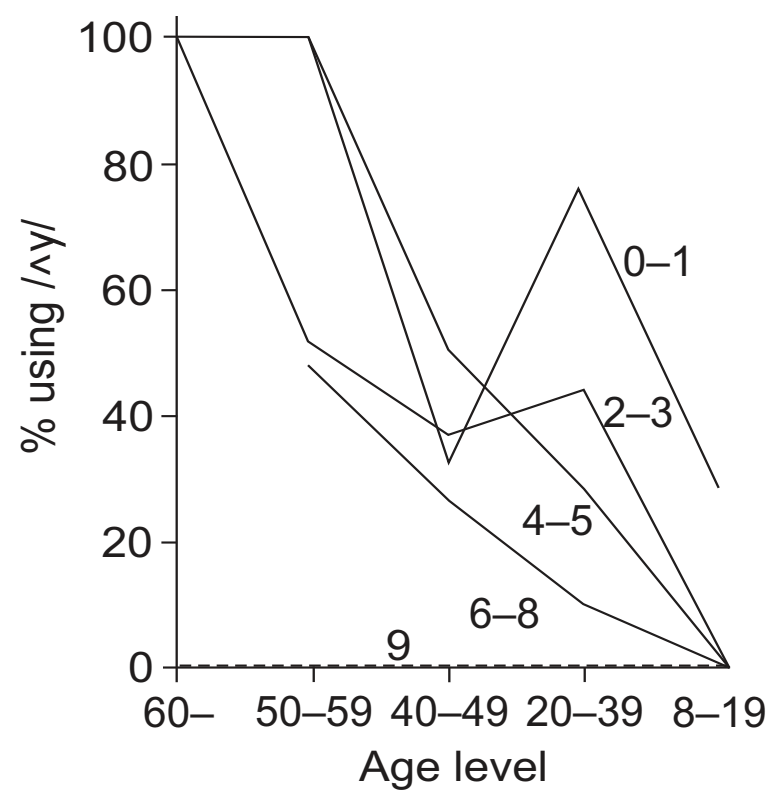

Figure 3: Retreat from diphthongal (r) in apparent time (Source: Labov 2006 [1966]:215, Fig. 9.3)

The pattern that Labov observed for coda (r) and the interdental fricatives was somewhat more complicated. In Figures 4 and 5 we see graphic representations of his findings for $(\mathrm{TH})$ and $(\mathfrak{x})$, where sparser data limited him to distinguishing only two age groups. ${ }^{2}$ For most of the social class groups, the use of occlusive pronunciations of $(\mathrm{TH})$ is increasing in apparent time, but the highest status group is headed in the opposite direction. The pattern is the same for (æ): a general tendency towards more raised variants, but divergent behavior in the highest social class. The results for coda (r) were similar, with the youngest speakers of the highest status group using progressively less of the NYCE vocalized or deleted variants, while the youngest speakers at other class levels showed relative increases in 'r-lessness' compared to their elders.

${ }^{2}$ In Figures 5 and 6, I have inverted Labov's scales for the sake of visual consistency, so that higher values indicate higher vowel articulations. 
(TH) in 1964

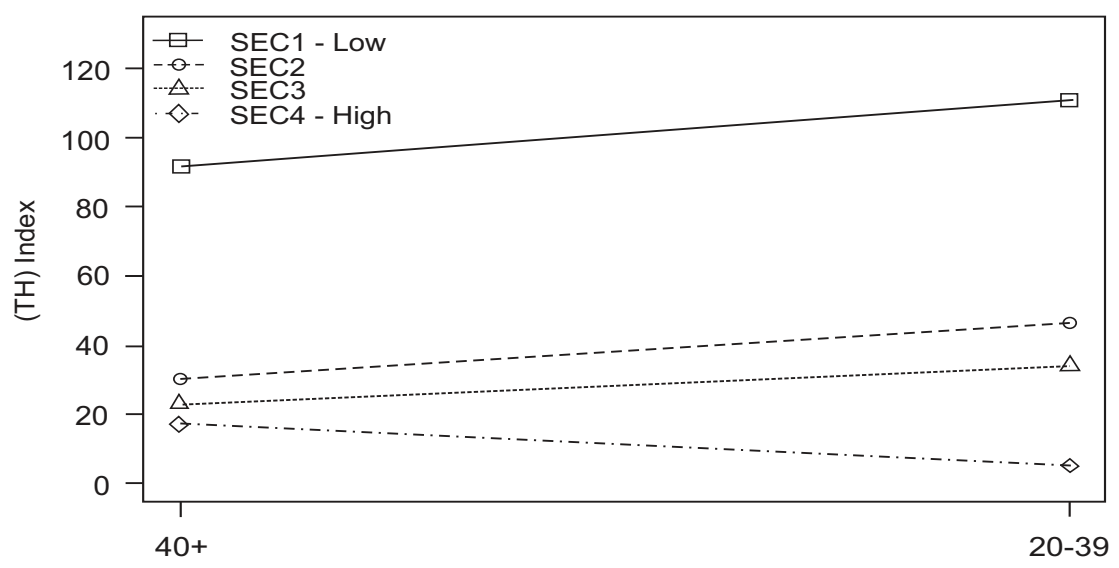

Age Group

Figure 4: $(\mathrm{TH})$ in apparent time: change from below with correction from above (after Labov 2006 [1966]:234, Table 9.18)

(aeh) in 1964

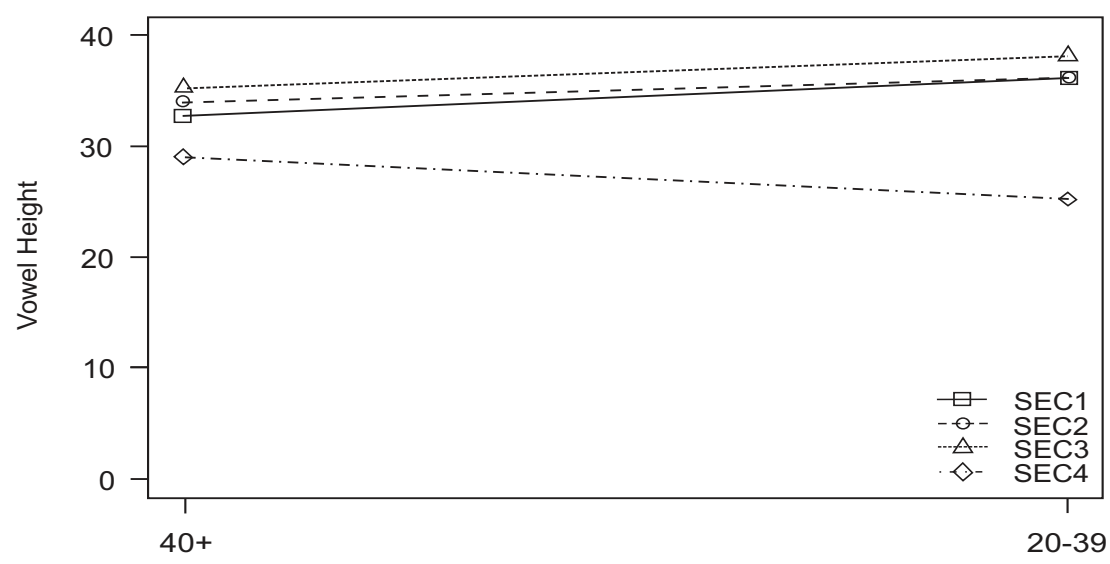

Age Group

Figure 5: (æ) in apparent time: change from below with correction from above (after Labov 2006 [1966]:227, Table 9.13)

These findings suggest that $(\mathrm{TH}),(\mathrm{DH}),(\mathfrak{x})$ and coda $(\mathrm{r})$ are also in the midst of an ongoing change, or rather, two contradictory changes. The local variants are advancing in the usage of most speakers, suggesting continuing change from below, while the highest status group has changed direction, indicating an incipient change from above in which a prestige norm targeting the usage of other American English dialects is being adopted. 
Cadernos de ESTUDOS LINGUÍSTICOS (58.3) - set./dez. 2016

The low back vowel in BOUGHT showed a third pattern in 1966, illustrated in Figure 6. For this variable, data were sufficient to distinguish a finer age gradation. Here the oldest speakers in the sample use lower variants than everybody else, but across the four younger age groups the age distribution is essentially flat. The ethnic differentiation between Jews and Italians mentioned above seems to be disappearing in the younger generations. Notably, the highest social class group systematically uses lower variants than the other speakers in the sample, which suggests that the local NYCE raised variant is already the object of a certain stigma in 1966. A reasonable interpretation of this pattern is that NYCE had an ongoing change raising the nucleus of BOUGHT up until the 1920s or 1930s (when Labov's 50-year old subjects were in childhood and adolescence), but subsequently the advance of this change was halted and social stratification began to emerge, indicating an emergent negative evaluation of the raised NYCE variant.

(oh) in 1964

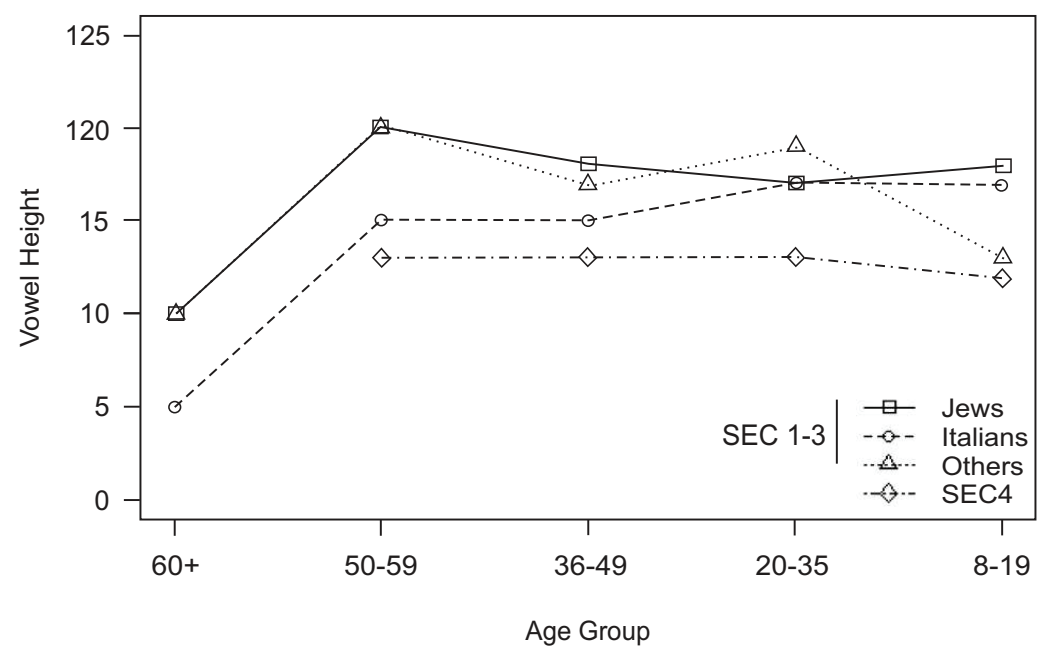

Figure 6: BOUGHT in apparent time: an inflection point? (after Labov 2006 [1966]:229, Table 9.17)

To summarize, the picture of NYCE that is evident in Labov's 1966 results is one in which the historical changes associated with NYCE are in broad retreat (diphthongal nuclear (r)), have ceased to advance (BOUGHT), or if still advancing, are showing incipient reversals of direction from above (interdental fricatives, coda (r)). Today, a half-century later, the obvious question is what has happened to these variables in the interim? Comparing Labov's results with what we can observe in the city today provides a unique time-depth for real-time speech community studies. 


\section{NYCE NOW}

Several recent studies of English in New York provide evidence suitable for comparison with Labov's account. Of the variables we have discussed, the NYCE trait that has received the greatest overt attention is r-lessness. One of Labov's investigations of this variable was his famous department store survey, in which he requested directions from numerous employees in large NYC department stores, which he knew would lead him to the 'fourth floor', a phrase in which coda (r) appears twice. He would then ask the subject to repeat the directions, yielding in most cases a second utterance of the phrase. The results showed that the rate of (r) usage depended on the status of the store: the store with the highest status reputation - Saks Fifth Avenue - had the highest rate of (r)-pronouncing among its employees, followed by Macy's, the mid-ranked store, and Klein's (which subsequently went out of business), the lowest. In the years since Labov's research, this study has been replicated several times, by Fowler (1986), Mather (2012), and in an unpublished study by myself and my students (2008). Twenty years after Labov's work, Fowler found the same relative ranking of the stores, but more (r) was being used in all of them. After another 20 years, we found a further advance in the rate of (r) use, and a neutralization of the difference between Saks and Macy's.

These successive studies thus provide a real-time comparison, effectively a trend study of (r) in New York City. The results are shown in Figure 7. The rate of (r) use increases continuously, apparently accelerating after 1986. In 45 years, (r) use has doubled in Saks and tripled in Macy's, essentially eliminating the difference between them.

\section{(r) in NYC departament stores - real time}

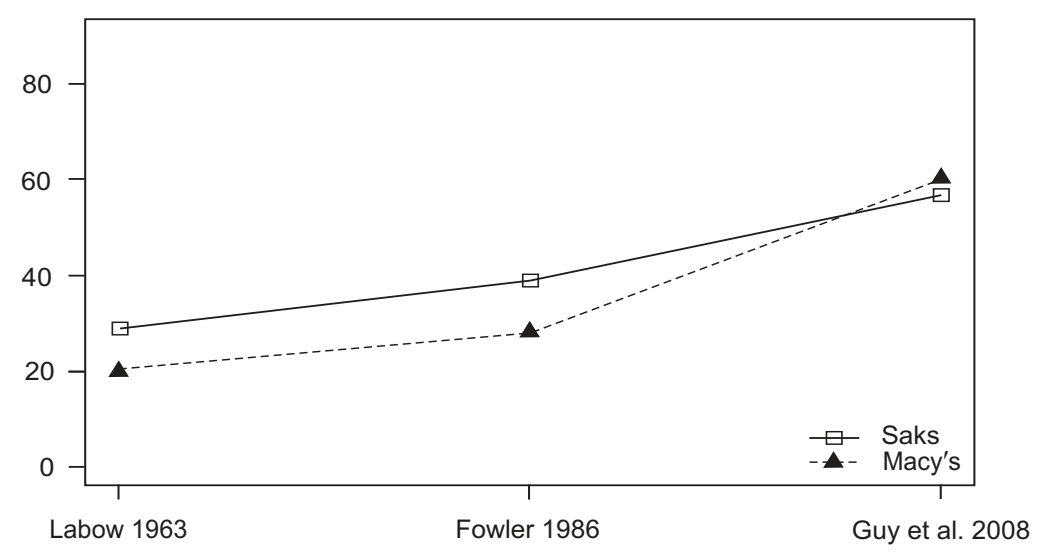

Figure 7: (r) use in NYC in real time 
Apparent time evidence for the history of this change can be obtained from the 2008 sample, in which we visually estimated each speaker's age. These data appear in Figure 8. Macy's employees show a steady increase in apparent time, while those at Saks show a relatively flat trend, having peaked in the $70-80 \%$ range some decades ago. These data offer an interesting comparison with the real time data shown in Figure 7. The oldest age group in our 2008 data were people over 50, who would have been born before 1958, meaning they would all have been in their linguistically formative years when Labov collected his data in 1963. But Labov found Macy's employees using only 20\% (r), while our over-50 Macy's employees are using over 50\%. These data suggest a strong possibility of life-span change having occurred in this community, with speakers increasing their rate of use of the incoming prestige form even during their adult years, much as Sankoff and Blondeau (2007) find for some speakers tracking the advance of uvular $/ \mathrm{r} /$ in Montreal French. If correct, this implies that the apparent time evidence in Figure 8 understates the rate of change; had our speakers remained stable in their use of (r) across the lifespan, the slopes of the trend lines would have been much steeper.

(r) in apparent time in 2008

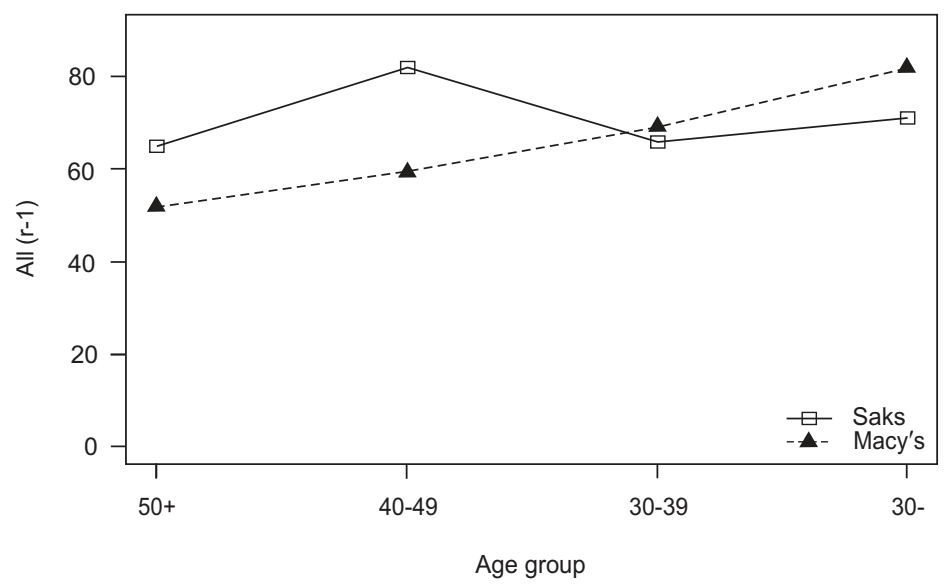

Figure 8: (r) use in 2008 by speaker age

The classic NYC vocalic variables investigated by Labov - the vowels of BOUGHT and TRAP - were re-examined in 2010 by Becker, who revisited the Lower East Side of Manhattan after more than 40 years had passed. She found dramatic evidence of rapid retreat from the raised nucleus reported in Labov 1966. Her data for BOUGHT are shown here in Figure 9. 


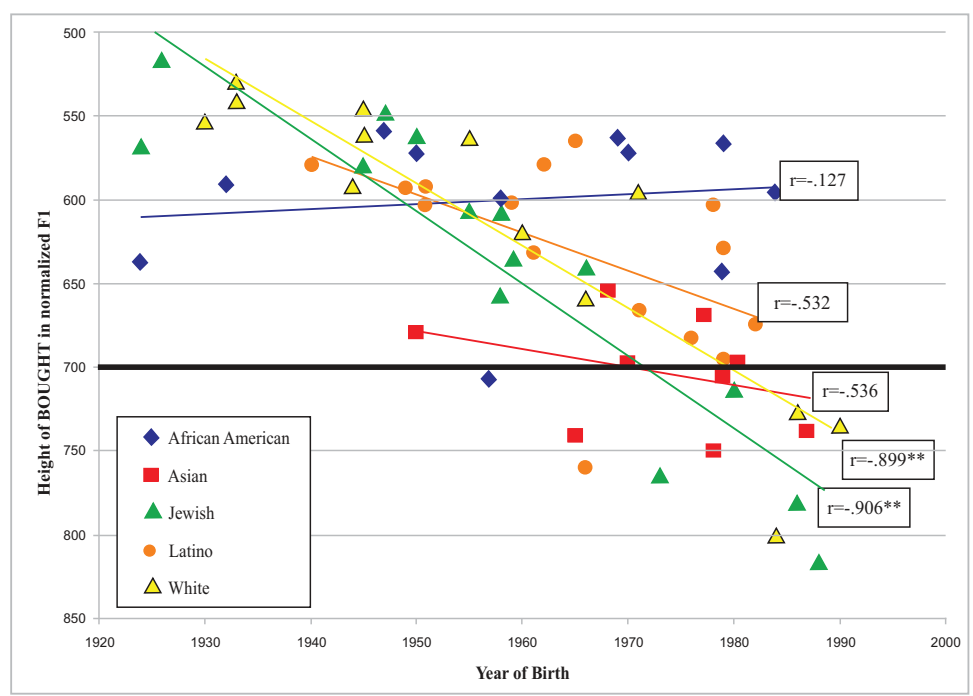

Figure 9: BOUGHT in 2010, by speaker age and ethnicity (Source: Becker 2010:121)

In apparent time, most of the subgroups Becker studied are moving rapidly towards lower variants of BOUGHT, led by Jewish and other white speakers, closely followed by Asian Americans and Latinos. Strikingly, in these data African Americans are not accompanying the change in the wider population, reflecting the continuing social and linguistic distancing of this community from the majority population.

What made the TRAP (æ) vowel distinctive in NYCE, more than its raised and fronted nucleus, was the allophonic or phonemic split of the vowel noted above, with tense and lax variants distributed in a baroque array of contexts. Similar splits are found elsewhere in the mid-Atlantic coastal regions of the USA. As noted above, the variants in NYCE were distributed as follows: the tense variant was found before tautosyllabic voiced stops, voiceless fricatives, and /m, n/, plus some lexical exceptions, while lax variants occurred elsewhere. However most of the United States has either systematic tensing of all TRAP tokens (the Inland North), or a simple nasal system where the tense variant occurs before all nasal consonants and the lax form elsewhere. (Note that in the nasal system, hang, bang etc. are tense, while in traditional NYCE such tokens before velar nasals were lax).

Becker's data from the Lower East Side show a retreat in apparent time from the fronted and raised position found by Labov for the tense variant (see Figure 10), but they also show that the traditional NYC conditioning pattern is breaking down, being replaced by the simple nasal system that characterizes much of US English. TRAP vowels occurring before velar nasals (marked by squares) have shifted from a backer alignment with the other lax contexts (diamonds) to a fronter position coincident with the other nasals, while tokens in non-nasal tense environments marked by triangles (before voiceless fricatives, voiced stops and in certain other words) merge with the lax contexts. 


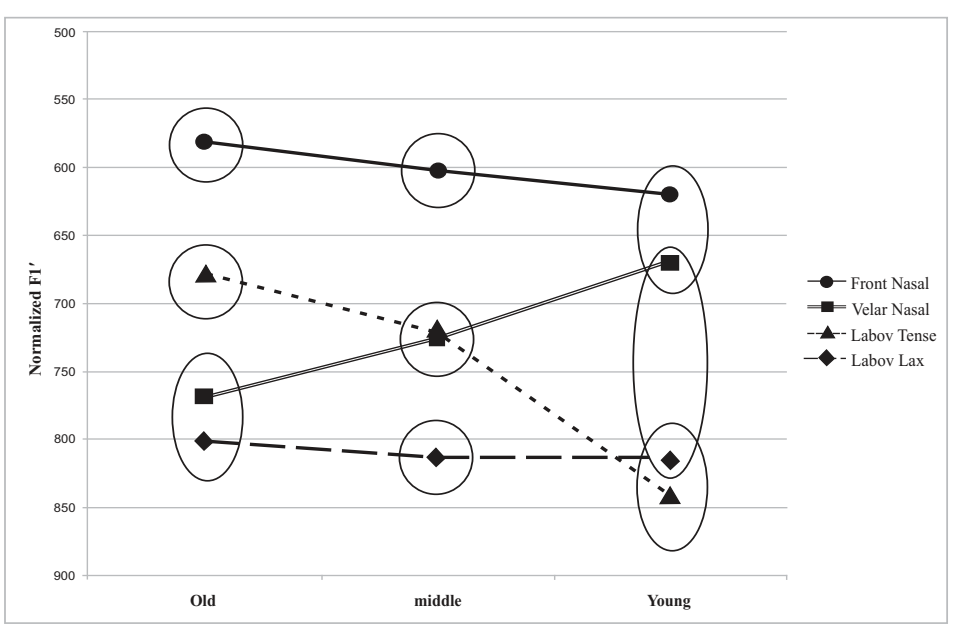

Figure 10: TRAP in 2010, by conditioning context and speaker age

(Source: Becker 2010:209)

\section{CONCLUSIONS: SOCIAL MOTIVATIONS FOR CHANGE}

The conclusion to be drawn from the linguistic evidence is that New York speakers are in a generalized retreat from all the traditional features of the city dialect. The data Labov collected in 1963 showed social stratification and stylistic stratification indicating that all the characteristic NYCE variants were stigmatized; his apparent time evidence suggested that they were all in the early stages of a change from above towards variants found in other adjacent dialects and more widely across the US. The most recent data available indicate that these changes have advanced dramatically: most younger contemporary NYCE speakers use little or none of the traditional city variants.

The obvious question that arises is 'why?' What motivated a wholesale flight from the linguistic traits that identified NYCE? Two factors merit exploration: stigma, and demographic change. The stratification and style shifting that is obvious in the earliest data are clear indicators of the stigma associated with features of the city dialect. It is also amply clear from language attitudes and popular culture that NYC English has been the object of negative evaluation and even derision in American society. New Yorkers who moved away from the city routinely experienced pointed comments or mockery about their speech; actors in film and television speaking with prominent NYCE accents were long depicted in roles that were intended as criminal, comical, foolish, working class: Jackie Gleason, Archie Bunker, the Godfather. Stereotypes of NYCE were widely disseminated in public and private discourse: "toidy-toid" and "coffee talk". So it is a social fact that NYCE has been a swamp of negative prestige in North America, but this in itself is an unusual situation. In many countries, for many languages, the largest and economically and politically most important city is the defining source of the standard, prestige variety: Parisian French, Beijing Mandarin, Moscow Russian, Madrid Spanish. Why is New York different? 
The answer to this paradoxical situation probably lies in the city's polyglot history. Uniquely among the original American colonies, New York was not founded by the English: it was first established as New Amsterdam, by Dutch settlers. After the English seized it in a colonial war, the Dutch population remained, and eventually underwent language shift to the use of English. As a city of foreigners, therefore, it was not a linguistic role-model for the pre-existing English colonies in Massachusetts, Rhode Island, Virginia, etc. In colonial times it was also less politically and demographically prominent than today: at the time of the American revolution, Philadelphia was the largest city in the colonies, and was the site of the Continental Congress when independence was declared. New York's rise to pre-eminence came in the 19th century, when the opening of the Erie Canal made New York the gateway to the Great Lakes region - the American Upper Midwest. This attracted vast numbers of immigrants from Europe, mostly non-English speaking. The city experienced explosive growth: the population of Manhattan grew from less than 100,000 in 1800, to over 2 million by the end of the century. Ellis Island became famous as the processing site for arriving immigrants. Foreign-born residents amounted to more than $40 \%$ of the city population from 1850 through 1910.

Throughout its history, therefore, New York City has had a large population of non-native speakers of English, and this is still true today. As noted in the introduction, the latest census figures report that almost half the population speak a language other than English at home. This is no doubt why the English spoken in the city has been poorly regarded by other regions of the US: it was perceived to be influenced by 'foreign accents', first Dutch, and then Irish, German, Italian, Yiddish, and now Spanish. The consequent stigma associated with the city dialect has been a driving factor in the loss of traditional NYCE features in the last halfcentury: a broad-based change from above, substituting the variants associated with neighboring higher-status varieties of English, found much more widely across American English.

But even without this history of stigma, the remarkable linguistic diversity of New York is itself implicated in the declining distinctiveness of NYCE. According to the US Census, in 2013 the city population was 8.5 million, of whom $33 \%$ were non-Hispanic whites, 29\% were Hispanic, 26\% were African American, and 49\% spoke a language other than English at home. This implies that the English-speaking (i.e. those who speak English at home), non-African-American population was just $26 \%$ at that time, which included substantial numbers of persons born elsewhere, as well as Latinos who spoke English at home. It is safe to assume, therefore, that the speakers who formed the core of the NYC speech community described by Labov - New York-born white native speakers of English - now constitute no more than a fifth of the population of the city. In a multi-polar multilingual city, this number may simply be insufficient for maintaining and transmitting the local dialect, and assimilating the continuing influx of immigrants. Newly arrived Haitians, Dominicans, Bangladeshis and Somalis may rarely encounter native speakers of NYCE. Given prevailing residential and occupational tendencies, most of their interactions in English are likely to occur with speakers of other 
Cadernos de ESTUDOS LINGUÍSTICOS (58.3) - set./dez. 2016

varieties and dialects: other immigrants, African Americans, and people from other parts of the US. Input from traditional NYCE speakers is unlikely to provide an adequate linguistic center of gravity towards which immigrants and their children will be attracted as they acquire English, and insofar as they become aware of the stigma associated with features of the city dialect, this would provide a further disincentive to emulate those features.

Research on migration clearly indicates that, over time, a shift to English will occur among the families and descendants of that half of the population of New York that currently speaks a language other than English at home. But what variety of English will they acquire? On present trends, it is unlikely that this variety will retain many distinctive traces of the English that Labov so memorably reported in 1966.

\section{$\overline{\text { REFERENCES }}$}

BECKER, Kara. Regional dialect features on the Lower East Side of New York City: Sociophonetics, ethnicity, and identity. PhD Dissertation. New York: New York University, 2010.

FOWLER, Joy. The social stratification of ( $r$ ) in New York City department stores, 24 years after Labov. NYU term paper, 1986.

GUY, Gregory; FURUKAWA, Alex; HACKNEY, Sarah; MAHBOOB, Rubaiyat; MANDEL, Ethan; WADDY, Kylie Replicating Labov's study of ( $r$ ) in New York City department stores. Unpublished manuscript, 2008.

LABOV, William. The social stratification of English in New York City. Arlington VA: Center for Applied Linguistics, 1966. [Second edition, 2006. Cambridge: Cambridge University Press.]

LABOV, William. Principles of linguistic change: Internal factors. Oxford \& Cambridge: Blackwell, 1994.

LABOV, William. Principles of linguistic change: Social factors. Oxford \& Cambridge: Blackwell, 2001.

LABOV, William. Principles of linguistic change: Cognitive and cultural factors. Oxford \& Cambridge: Wiley-Blackwell, 2010.

MATHER, Patrick-André. The social stratification of /r/ in New York City: Labov's department store study revisited. Journal of English Linguistics, v. 40, n. 4, p. 338-365, 2012.

SANKOFF, Gillian; BLONDEAU, Hélène. Language change across the lifespan: /r/ in Montreal French. Language, v. 83, n. 3, p. 560-588, 2007. 